\title{
AC 2007-951: ENGINEERING ENTREPRENEURSHIP FOR HIGH SCHOOL AND EARLY COLLEGE STUDENTS
}

\section{Karen High, Oklahoma State University}

KAREN HIGH earned her B.S. from the University of Michigan in 1985 and her M.S. in 1988 and Ph.D. in 1991 from the Pennsylvania State University. Dr. High is an Associate Professor in the School of Chemical Engineering at Oklahoma State University where she has been since 1991. Her main research interests are Sustainable Process Design, Industrial Catalysis, and Multicriteria Decision Making. Other scholarly activities include enhancing creativity in engineering practice and teaching science to education professionals. Dr. High is a trainer for Project Lead the Way pre-Engineering curriculum. Dr. High is involved with the development of an undergraduate entrepreneurship program at Oklahoma State University.

\section{Paul Rossler, Oklahoma State University}

PAUL E. ROSSLER directs the Engineering and Technology Management Program and co-directs the Legal Studies in Engineering Program at Oklahoma State University and is an Associate Professor of Industrial Engineering and Management. He is a licensed professional engineer and holds a M.S. and Ph.D. in industrial engineering from Virginia Tech.

\section{Martin High, Oklahoma State University}

MARTIN S. HIGH founded and co-directs the Legal Studies in Engineering Program at Oklahoma State University and is an Associate Professor of Chemical Engineering at Oklahoma State University. Professor High earned his B.S., M.S., and Ph.D. in chemical engineering from Penn State, and a J.D. from the University of Tulsa. He is licensed as an attorney in Oklahoma, registered as a Patent Attorney to practice before the United States Patent and Trademark Office, and licensed as a professional engineer in Pennsylvania. 


\title{
Engineering Entrepreneurship for High School and Early College Students
}

\begin{abstract}
Project Lead the Way, Inc. ${ }^{1}$ is a national pre-engineering curriculum that involves partnerships among public schools, higher education, and the private sector to increase the quantity and quality of engineers and engineering technologists graduating. More than 660 state high school students are currently enrolled in the curriculum. The Engineering Design and Development (EDD) module is a capstone course for senior high school students, focusing on invention and entrepreneurial skills. Dr. Karen High serves as a trainer for this course. The module includes innovation and invention, and shows students how to take engineering one step further.
\end{abstract}

A one-credit hour engineering orientation course was developed in the fall of 2006 that introduced engineering entrepreneurship to former Project The Lead the Way studentsnow enrolled as college freshman - as well as other freshman engineering students. Engineering and business faculty members, along with a focus group of entrepreneurs, were involved in the course's development. At the beginning of the course, the design cycle for product and process innovation, as well as problem definition, was described. A number of outside business speakers provided insight into the world of entrepreneurship, including teamwork, intellectual property, business and marketing plans, international and social entrepreneurship, and ethics. The students engaged in critical thinking exercises and worked on projects to develop marketing and business plans for projects based on inventions. Examples of course curriculum, and retention and recruitment statistics, are presented.

\section{Background}

The typical model of engineering education — students seek out a university for a technical education and then, in their senior year, seek out an established employer for a job-has not necessarily served the needs of the State of Oklahoma in recent years. Vast numbers of students who graduate with technical degrees from Oklahoma State University seek employment in surrounding states, particularly Gulf Coast states. As a result, Oklahoma's higher educational system serves to support the economic well-being of neighboring states. This begs the question of whether a different model of technical education is needed at Oklahoma State University, one in which students are trained in entrepreneurial skills and, rather than seeking an employer as graduation draws near, begin businesses within the state or join entrepreneurial firms within the state.

It is unlikely that an entrepreneurial mindset of the required risk taking can be taught. But, it is likely that the skills required to make those with an inclination toward entrepreneurship more successful can be taught. In addition, a degree program that focuses on entrepreneurship might prove successful in: (1) attracting students into the engineering program who are seeking educational opportunities in entrepreneurship, or who might otherwise gravitate toward other majors and (2) fostering student creativity 
and drive to improve the economic climate of our state. While the design of a four-year entrepreneurship program represents a large, long-term undertaking, smaller, more manageable efforts can be taken at the present time. This paper describes one such effort.

The impetus for this effort came from considering the experience of other first year engineering entrepreneurship approaches.. For example, one such program at George Mason University (Dabbagh and Menasce ${ }^{2}$ ) used a market game to engage a pilot group of students in forming IT companies, while other students were given a traditional engineering design project. Assessments showed that the students who used the market game had a higher, overall positive perception of engineering entrepreneurship and professional skills. Although retention and interest in staying in engineering was not assessed by the George Mason researchers, others have examined the effect of entrepreneurship education on retention, as well as professional skills and GPA (Bilen, et al. ${ }^{3}$, Creed et al., ${ }^{3}$ Standish-Kuon and Price ${ }^{5}$ for example). In addition, other researchers have explored the justification for including entrepreneurship in freshman engineering education $\left(\right.$ Johnson $^{6}$ ). Exposure to entrepreneurship during the freshman year exposes the students to the design process, professional skills, ethics, and effective communication - topics that remain important throughout their engineering education and subsequent technical and business careers.

\section{Project Lead the Way ("PLTW")}

"Project Lead the Way is all about teaching and learning. The hands-on, project and problem-based PLTW approach adds rigor to traditional technical programs and relevance to traditional academics."[CITE] The PTLW approach introduces creative problem-solving and business issues into middle school and high school curriculum. This approach allows students to experience technical problem solving in a very applied manner, which then reinforces their academic subjects.

Dr. Karen High has served on a PLTW program advisory committee since spring 2006; has observed student presentations of projects for the senior capstone course and Engineering Design and Development (EDD) module; and has served as a judge for another state PLTW EDD presentation competition in 2006. At the same time, Oklahoma State University became an affiliate university for the PLTW program. This means that Oklahoma State University will train nationwide teachers in the summer of 2007 and beyond in PLTW curriculum. Dr. Karen High was trained in the summer of 2006 in the EDD curriculum. The EDD curriculum very much engages the high school seniors in the entrepreneurial skills of problem definition, patent searching, prototype design, competitor analysis, and business plans.

Based on these experiences, the Dr. Karen High felt that a focus in the freshman-level class towards entrepreneurship would be appropriate. Thus, two sections of Introduction to Engineering were developed. A specific attempt was made to recruit PLTW graduates into the entrepreneurship sections. 


\section{Introduction to Engineering Course}

The major goal of this course is to increase the retention of freshman engineering students by introducing the students to engineering concepts and experiences. Another major goal of the course is to address ABET's 'professional' skills learning outcome requirement. Overall, there are 25 sections of the course that are taught in the college with each section typically having 21 students. Dr. Karen High taught three of these sections, with a total enrollment of 66 students, in the fall 2006 term. Two of these sections focused on engineering entrepreneurship. The other section followed the traditional course curriculum.

The two engineering entrepreneurship sections each met for 15 hours during the semester, and extra time was provided for meetings with success coaches and peer mentors. The six main areas covered in the sections are detailed below:

- Academic Success- study skills, time management, finding help for classroom material, test-taking skills, and college survival skills.

- Professional Success - career planning and effective presentations.

- Engineering Information - career and advisement information and research presentations/laboratory tours.

- Engineering Design and Problem Solving - creativity, effective teams, brainstorming, process design, and product design.

- Societal Issues of Engineers - ethics, diversity/international issues, environmental issues/sustainability, medicine and bioengineering.

- Personal Development - stress management and other wellness issues.

\section{Demographics of Students}

The demographics of the two engineering entrepreneurship sections are given as follows: Section A:

23 students (one student is under 18 and therefore did not participate in assessment), 16 male and 7 female

All engineering majors

One of the first sections of Engineering 1111 to fill up (class enrollment usually is limited to 21 students)

Four students were in a PTLW program in High School

Section B:

24 students, 19 male and 5 female

All engineering majors

Section opened up during the middle of summer enrollment after Section A filled

Three students were in a PTLW program in high school

\section{Course Activities}

A number of activities were provided to the students to give them exposure to engineering and entrepreneurship. The first activity involved the following topics: (1) 
Introduction/Welcome/Success Coaches; (2) Get to know each other; (3) Blackboard (the courseware program) /facebook/lab books; (4) What do Engineers do?; and (5) What is Entrepreneurship? The other main activities of the course involved course speakers, IDEO video, the 'Ding Dong' activity, an airplane design challenge, and a business plan project that had the students working on either an ergonomic collapsible cart or a windmill invention.

\section{Course Speakers}

The instructors of the course selected a variety of speakers to address issues that were relevant to entrepreneurship:

- Dr. Marty High and Susan Holcomb - Intellectual property and legal issues; patent searching.

- Cathy Southwick, College Career Services, - Resumes, career coaches

- Mark Wilson, Coronado Resources - Applying entrepreneurship skills in industry and in your own business

- Peter Abramo, Cameron University and MEAPA - Business and Marketing Plans

- Ron Morgan, Halliburton - Teamwork

- Oklahoma State University Student Panel

- Hope Ray, Study Abroad Office - Opportunities for Study Abroad for Engineering Students

- Lacy Landrum, Technical Communications - Presentation Skills and Technical Writing

- Steve Price, Oklahoma State University Associate Vice President for Technology Transfer - International and Social Entrepreneurship

- Kevin Drees, Library - Library Resources

- Ron Morgan, Halliburton - Ethics

\section{$\underline{\text { IDEO Video }}$}

In the third week of the semester, the design process was outlined in class. The design process that was followed was one given to Dr. Karen High by the EDD trainer, Stan Warwrzyniak. ${ }^{7}$

Identify a Problem - from many possible problems, choose a final problem by:

- verifying that the problem is a problem,

- justifying the problem based on expert sources,

- finding NO significant existing solution,

- summarizing the problem with a problem statement,

- summarizing solution requirements

Propose a Solution - from many possible solutions, choose a final design by:

- generating a large volume and wide variety of creative solutions,

- identifying the pros and cons of related solutions,

- proposing workable designs that meet requirements,

- identifying a final design based on evaluation of workable designs,

- justifying the final design based on expert sources,

- documenting the final design in detail. 
Test the Solution - by:

- prototyping the design,

- testing the design.

The students then watched an engaging video about the California-based product development company, IDEO that set out to redesign the shopping cart. The following is the out of class assignment.

"Using Microsoft Word or other computer document software, write a brief summary of the IDEO video. Did they follow the design process as outlined in class? What did you like or not like about the video? What other comments do you have? This should be about 200 words."

The students wrote some very intriguing reflections of the IDEO video. Comments included:

“IDEO's approach to design and production may seem way out of line to some, but I, personally, think that it is genius. By creating a creative environment, workers no longer are workers, but kids in a sandbox, just trying to figure out the best way to make things work."

"IDEO studied how customers use the carts to get a better idea for their design."

"I liked that the video outlined the entire design process from start to finish. Also the video showed how the IDEO work environment is playful and inviting."

"IDEO is a company that looks at normal everyday problems, then gets a diverse team together and fixes the problem."

"The IDEO group working on the shopping cart did not follow the design process exactly, because they only needed to propose a solution. . . . The problem was brought to them"

"I liked the movie. It showed me a lot of what an engineer's life may be like."

"I like the fact that the team consisted of people from a variety of fields. From psychologists, to chemists, to engineers, to businessmen, there was room to produce a large amount of ideas that were varied and unique.

From these comments it is clear that the students understand the design process, consider aspects of invention, and really like a creative environment. They also appreciated the need for diverse teams to work on projects.

\section{Ding Dong Activity}

The goal of this activity is to have the students learn to define problems. The students are shown a box of Ding Dongs that are squished and the students are asked to follow the problem-solving strategy of Fogler and Leblanc ${ }^{8}$ to solve the problem:

1. Problem Definition

2. Brainstorming solutions 
3. Deciding a course of action

4. Implementing the solution

5. Evaluating the solution (which may require iteration with number 3)

The students worked in teams and completed the following group work:

1. Define the problem. Give at least ten possible problems.

2. Provide solutions to at least two of the problems (give at least five solutions for each).

3. Decide a course of action (which problem would you work on and which solution).

Then the students were asked to complete the following out of class assignment:

"Do the following in a few sentences each (use Microsoft Word)

1. Describe your impressions from the Ding Dong activity.

2. How well did your group function together?

3. Describe your group's brainstorming capabilities.

4. Give a definition of problem solving and problem definition in general.

5. Your group should have come up with one problem and one solution to work on. How might you implement the solution (i.e., experiments to test) and how might you evaluate the solution?

6. What do you think engineering is? What does an engineer do?"

Student comments from this take home assignment were very interesting:

"It was very interesting to say the least. It got most of us thinking creatively"

"It was a nice team builder activity."

"Our brainstorming was successful because everyone had ideas, and they were all a little bit off the wall and sometimes far-fetched. In the end, I think it helped us introduce better solutions."

"Engineering is looking at the world and finding ways to improve it."

"I think engineering is problem solving"

These comments show that the students were able to understand the problem definition part of entrepreneurship. The also understood the role of brainstorming and were aware of what engineering is all about.

\section{Airplane Design Challenge}

The airplane design challenge was developed for this course because it is problem-based, gives students a chance at cooperative learning, involves dialogic opportunities for thinking, makes students consider other perspectives, builds team learning, promotes student engagement, simulates how the design process works, and helps them make connections to what engineering is all about.

The airplane challenge is done in the fifth week of the semester because the students have had a chance to get to know each other a little. Also, it gets them engaged early enough so that they use these experiences to help in a later semester activities. The airplane challenge is an activity that is done in a fifty minute class period. The students first are 
placed in a group of three to four and then tasked with determining a group name. Once they have the names determined they are given a handout with the challenge (Table 1).

\section{Table 1 - Airplane Challenge}

Given the following items:

Product/Process Airplane Design Challenge

Toothpicks

Rubber bands

Paper clips

Post it notes

Gum
Ziploc bag

Lunch bags

Tootsie rolls

Lifesavers

Design an airplane using materials given (10 minutes)

Place prototype at front of classroom on paper along with group name

Design a process/method to manufacture the airplanes (5 minutes)

Be aware that I will provide calamities/upsets

Build airplanes (10 minutes)

Deliver your airplanes in one (or more) lunch bag to the front of the classroom

next to the prototype

Group name must be on lunch bag

Evaluate products (5 minutes)

Rank (individually) the group designs for those that meet specifications (looks like an airplane)

Next week I will tell which group "won"

Equal weights to product design/process design.

Keep track of activities/thoughts in your lab book!!!!!!!

The teams are to take toothpicks, rubber bands, paper clips, tootsie rolls, post it notes, lifesavers and gum and design a prototype airplane (that doesn't have to fly). The team then designs a process to manufacture the airplanes considering that process calamities and upsets might occur during this phase. For example, a student might be made to simulate a work related accident by not allowing them to use an arm, or supply chain issues are simulated by removing some of their tootsie rolls, or power outages are simulated by shutting off the lights and not allowing anyone to work. The teams then build as many airplanes as they can in 10 minutes and deliver them in a shipping container (lunch bag). All students then rank individually the group designs for those that meet specifications (looks like an airplane). The team that receives the most points wins the product design contest. The process design contest is won by the team that produces the most airplanes. The students kept track of details in a lab notebook.

The students were also given a writing assignment at the beginning of the hour so that they knew what was expected of them. This provided an opportunity for meaningful entries in their lab books. The writing assignment was due in the seventh week of the semester, two weeks after the in-class challenge. The assignment had them consider whether the challenge was a good exercise to understand the differences between product and process design. Design resources ${ }^{9,10,11,12}$ were given that helped the student better 
understand engineering product and process design concepts. The outcome of this assignment was that the students felt that this activity was a great way to show how product and process design relate and are different.

\section{Business Plan Project}

For this project the students were asked to complete a business plan assignment. For this the students had the option of developing a plan for either a windmill designed and patented by Lewis Miller ${ }^{13}$, an ergonomic collapsible cart designed by Dr. High (patent being developed), or something else of their choice. Two of the speakers provided information to help the students develop business plans

Peter Abramo told students in his presentation, "What Do You Include in the Business Plan," to include the following:

- Executive Summary

- Business Model

- Product/Service Definition

- Market Definition

- Competitive Landscape

- Marketing Plan

- Management Team

- Implementation Plan

- Financials

- Funding Terms and Exit Strategy

Bharat Chahar suggested the following:

- What is a Business Model?

- How and why is the business going to make money?

- Elements of a Business Model

- What would we sell?

- Who would we sell it to?

- Why would anyone buy it from us?

- How would competition respond?

- What differentiates us from others?

- Why couldn't others do the same as us?

- What would it take to be profitable?

- Need to Understand

- Strength, weaknesses, assets, skills, competitors, customers, markets, trends etc.

The students worked on these projects in teams of three to four students over the semester and gave end of semester presentations. The teams were selected to be multidisciplinary. 


\section{Assessment}

An end-of-course assessment survey was given to both sections of the Introduction to Engineering Course. University Institutional Review Board approval was given for the survey. The survey was anonymous, with the only identifier being which section the students were in. The survey had three sections and the assessment was evaluated after the semester was over and after course grades were turned in. There was one student who could not participate in the survey because she was not 18 and, therefore, could not give her consent. Two students from Section B did not complete the assessment. The total sample size was 44 students.

\section{$\underline{\text { Section } 1}$}

Q1. I am comfortable using an Inventor's notebook.

Q2. I know the concepts of product and process innovation.

Q3. I understand engineering design approaches.

Q4. I understand problem definition and problem solving

Q5. I am comfortable working in groups/on teams.

Q6. I am confident in my brainstorming and creativity abilities to solve problems.

Q7. I am confident giving presentations using Power Point.

Q8. I am confident in my MS Word and EXCEL abilities

Q9. I understand what entrepreneurship is.

Q10. I am confident in developing a business plan.

Q11. This course has encouraged me to take business classes.

Q12. This course helped me decide to stay in engineering.

Q13. I would consider pursuing an engineering entrepreneurship degree if it were offered.

The students were given a 5-point Likert Scale to evaluate their agreement with the above statements. Strongly disagree was 1 and strongly agree was 5. Table 2 shows the results for Section 1 of the assessment for both sections A and B.

Table 2 - Results for Section 1

\begin{tabular}{|c|c|c|c|c|c|r|r|r|r|r|r|r|c|}
\hline & Q1 & Q2 & Q3 & Q4 & Q5 & Q6 & Q7 & Q8 & Q9 & Q10 & Q11 & Q12 & Q13 \\
\hline $\begin{array}{c}\text { Section } \\
\text { A }\end{array}$ & 3.73 & $\mathbf{4 . 1 8}$ & 4.00 & $\mathbf{4 . 3 2}$ & $\mathbf{4 . 5 0}$ & $\mathbf{4 . 2 7}$ & 3.86 & 3.91 & $\mathbf{4 . 3 6}$ & 3.50 & 3.36 & 3.41 & 3.52 \\
\hline $\begin{array}{c}\text { Section } \\
\text { B }\end{array}$ & 3.64 & 3.95 & 4.00 & $\mathbf{4 . 1 8}$ & $\mathbf{4 . 3 2}$ & $\mathbf{4 . 2 7}$ & $\mathbf{4 . 1 4}$ & $\mathbf{4 . 3 2}$ & $\mathbf{4 . 0 5}$ & 3.77 & 3.59 & 3.68 & 3.41 \\
\hline
\end{tabular}

5=Strongly agree, $4=$ agree, $3=$ neutral, $2=$ disagree, $1=$ strongly disagree.

Bold numbers indicate the numbers where the average was above "agree" (value of 4 ).

A paired t-test between the two sections that showed that there were no significant differences between the two sections at $\mathrm{p}<0.05$, a statistically significant difference at the $95 \%$ confidence level.

The students were in high agreement for a number of statements. One statement where both sections were in high agreement was Q4, "I understand problem definition and problem solving." This is an expected result because of the IDEO video, Ding Dong exercise, and the ergonomic collapsible cart assignment that tasked with problem definition and problem solving. Additionally, the statement Q5, "I am comfortable 
working in groups/on teams" was also expected due to the high number of cooperative/collaborative activities that were completed in the class for both sections. Agreement for Q6 was also high for both sections, "I am confident in my brainstorming and creativity abilities to solve problems." Q9, "I understand what entrepreneurship is" also received high agreement; again due to the structure of the class, group project and speakers.

To determine future directions for an entrepreneurship, the authors asked the students for their agreement with three statements. For all three statements, "This course has encouraged me to take business classes," "This course helped me decide to stay in engineering," and "I would consider pursuing an engineering entrepreneurship degree if it were offered" there was between neutrality and agreement given. When looking at raw numbers, 13 students from Section A and and nine students from section B were in agreement with taking business courses. Nine students from Section A and seven students from section B were in agreement that this course helped me decide to stay in engineering. While initially disappointing, the authors think that many of the students in the sections were already motivated to stay in engineering, so that this course didn't affect that decision. One of the main purposes of the Introduction course is for retention. Ten students from each section for a total of 20 out of 46 are interested in an entrepreneurship engineering degree. This is extremely encouraging and provides motivation for the authors to develop such a program or a smaller minor program.

\section{$\underline{\text { Section } 2}$}

The students were given a 5-point Likert Scale to evaluate their evaluation of the effectiveness of the speakers. Not effective was 1 and extremely effective was 5. Table 3 shows the results for Section 1 of the assessment for both sections A and B.

Table 3 - Evaluation of the course speakers

\begin{tabular}{|c|c|c|c|c|}
\hline & $\begin{array}{c}\text { Section } \\
\text { A } \\
\text { Ranking }\end{array}$ & $\begin{array}{l}\text { Section } \\
\text { A } \\
\text { Values } \\
\end{array}$ & $\begin{array}{c}\text { Section } \\
\text { B } \\
\text { Ranking }\end{array}$ & $\begin{array}{c}\text { Section } \\
\text { B } \\
\text { Values } \\
\end{array}$ \\
\hline Intellectual property and legal issues & $4 *$ & 3.95 & 5 & 3.64 \\
\hline Resume/Career Services & 8* & 3.71 & 9 & 3.41 \\
\hline Applying entrepreneurship skills in industry and in your own business & 3 & 4.11 & $3 *$ & 3.86 \\
\hline Business and Marketing Plans & $4 *$ & 3.95 & $3 *$ & 3.86 \\
\hline Teamwork & 1 & 4.53 & 1 & 4.27 \\
\hline Student Panel & 11 & 3.42 & 12 & 3.16 \\
\hline Study Abroad & 10 & 3.67 & 10 & 3.23 \\
\hline Technical Writing/Presentation Skills & 8* & 3.71 & 8 & 3.45 \\
\hline International and Social Entrepreneurship & $4 *$ & 3.95 & 6 & 3.62 \\
\hline Entrepreneurship vs. Inventorship & 7 & 3.84 & 7 & 3.52 \\
\hline Library & 12 & 2.95 & 11 & 3.20 \\
\hline Ethics & 2 & 4.45 & 2 & 3.95 \\
\hline
\end{tabular}

5=Extremely effective, 4=Very effective, 3=Effective, 2= Slightly Effective, 1=Not effective

Bold scores are for those topics that the students found Very or Extremely Effective

* Indicates a tie between that particular topic and one or more other topics 
All of the speakers received effective to extremely effective scores from the two sections. This is important to note as this suggests that the authors provided the students with a rich array of topics and appropriate speakers. The topic and speakers that received the highest rating were teamwork and ethics. The authors were not surprised by the teamwork topic receiving a high score because the speaker engaged the students in an active learning activity that showed the students what type of team member they were along with other personality traits. A surprising statistic was that the students ranked ethics as high. This is commonly considered to be a "boring" subject by the students. However, the two speakers provided very engaging conversations about this important topic.

Looking at the low end of the list, it was not surprising that the students did not find the library as effective as the other topics. The speaker for this topic spends time having the students search databases. He provides the students with a generic assignment that is given to all 25 sections of the course. The authors plan to work with the speaker to make this a more effective presentation. One way might be to tailor an assignment to entrepreneurship topics. It was very surprising that the students didn't rank the student panel higher. This was a very engaging conversation where student leaders talked about engineering, job prospects, design challenges that they had been a part of, and more. It was also disappointing that the students didn't value the study abroad speaker more.

\section{Section 3}

Q1. When did you register for this section of Engineering 1111 ? During summer enrollment In the early fall

Q2. What made you decide to enroll in an Engineering Entrepreneurship section?

Q3. Were your expectations met? Why or why not?

Q4. List your definition of engineering entrepreneurship.

Q5. Do you plan to stay in Engineering? If so, what major? If not, what major are you switching to?

Q6. How did this course effect your decision to stay in or leave engineering?

Q7. How could the Drs. High have improved your experience in this course?

Q8. Other comments?

Eighteen of the 22 students that took the assessment in Section A enrolled in the summer, and 17 of the Section B students enrolled in the summer (Q1). Most of the other students "switched into" the entrepreneurship sections. Expectations were met for 19 of the Section A students and for 18 of the Section B students (Q3). Three of the students were in Architecture to begin with and chose to take this class because it sounded like fun. Of the 41 students that completed the survey, 36 are staying in Engineering (81.8\%) (Q5). The five other students are switching to nutritional sciences, advertising, accounting, Spanish/English, and one undecided. Of the students staying in engineering, the students are pursuing - chemical (13), mechanical (10), civil (5), electrical (2), industrial (2), aerospace (1), and not listed or undecided (3). 
Comments from the students on question (Q2) of the assessment included:

"It is an unusual sounding course, and also I was very interested in the business side of engineering. I also wanted to be one of the first to take this course since this was the first time it is offered."

"I was interested in the design process and be able to use creativity to solve problems."

"I was planning on becoming an engineer, and during my enrollment time Dr. High spoke and she was very interesting and I wanted to have her."

"I thought it would be good for me to be shown a more business-side of engineering."

"Interests in patents and business."

Comments from the students on question (Q4) of the assessment included:

"Engineering entrepreneurship takes simple engineering to the next level. Many people involved in engineering entrepreneurship are involved in inventing and marketing their own products."

"Using business sense \& entrepreneurship to develop engineering ideas."

"A combination of both engineering and entrepreneurship, designing the product and marketing."

"The application of business to engineering in the product design process."

"Using your engineering to be a business entrepreneur."

"Designing some project and knowing when to take the risk to market, sell, and promote the product."

Comments from the students on question (Q6) of the assessment included:

"The guest speakers made it a reinforcement of a career I desire."

"It gave me a lot of insight as to what engineering is really about.'

"It influenced me by encouraging me to be more involved with the engineering college, the engineering clubs, and college in general."

"This course was fun and the assignments were interesting."

"This course helped me recognize the overall flexibility engineers have. They really can do anything."

"It helped me stay. It showed me another option of a profession other than plain engineering."

Comments from the students on question (Q7) of the assessment included:

"They did a great job and made the class worthwhile. A little less speakers would be better."

"Put announcements on the blackboard announcement page more often."

"I think it was excellent!!! :)"

"I felt like they made it fun and a good experience."

"I think they did a good job - generally friendly and easily accessible."

"I think the only way is to make the course longer, so we could have spent more time with them." 
Interestingly, one of the students that identified themselves as from a PLTW said that they would have liked a bigger project like they had in EDD. Another PLTW student felt it was an "echo of last year."

\section{Concluding Comments and Future Directions}

The Project Lead the Way, Inc. program was used as a springboard for an introductory engineering course at the freshman level. This one-credit hour engineering orientation course was developed in the fall of 2006 and introduced engineering entrepreneurship to former Project The Lead the Way students-now enrolled as college freshman - as well as other freshman engineering students. Engineering and business faculty members, along with a focus group of entrepreneurs, were involved in the course's development. Outside business speakers provided insight into the world of entrepreneurship, including teamwork, intellectual property, business and marketing plans, international and social entrepreneurship, and ethics. The students engaged in critical thinking exercises and worked on projects to develop marketing and business plans for projects based on inventions.

The student response was extremely positive. $87.8 \%$ of the engineering students in this section have indicated that they plan to stay in Engineering. Five students have chosen to change majors to nutritional sciences, advertising, accounting, Spanish/English, and one undecided. The concept of using entrepreneurship at the freshman level as a retention tool appears to have merit. The written comments from the students indicate that they were happy with their experience in the course which also has a positive retention impact.

This course was a trial program to gauge the usefulness of using an entrepreneurship program as a retention mechanism. It is the authors hope to leverage this experience into developing a minor program in the College to attract and retain students that would otherwise pursue more business-oriented curricula.

\section{Bibliographic Information}

(1) Project Lead the Way Website, http://www.pltw.org/index.html.

(2) Dabbagh, N., and D. Menasce, "Student Perceptions of Engineering Entrepreneurship: An Exploratory Study," Journal of Engineering Education, 95 (2), 2006, pp. 153-164.

(3) Bilen, S., E. Kisenwether, S. Rzasa, and S. Wise, "Developing and Assessing Students Entrepreneurial Skills and Mind-Set," Journal of Engineering Education, 94 (2), 2005, pp. 233-243.

(4) Creed, C., E. Suuberg, and G. Crawford, "Engineering Entrepreneurship: An Example of A Paradigm Shift," Journal of Engineering Education, 91 (2), 2002, pp. 185-195.

(5) Standish-Kuon, T. and M. Price, "Introducing Engineering and Science Students to Entrepreneurship: Models and Influential Factors at Six American Universities," Journal of Engineering Education, 91 (1), 2002, pp. 33-39. 
(6) Johnson, M., "Engineering Entrepreneurship: Does Entrepreneurship Have a Role in Engineering Education?," IEEE Antennas and Propagation Magazine, 45 (1), 2003, pp. 134-138.

(7) Warwrzyniak, S., Engineering Design and Development, Project Lead the Way Summer 2006 Training Course Notes, New Hampshire Technical Institute, Concord, NH.

(8) Fogler, H., and S LeBlanc, Strategies for Creative Problem Solving, Prentice Hall, Upper Saddle River, NJ, (1995).

(9) Lumsdaine, E. and M. Lumsdaine, "Chapter 13-What is Design," Creative Problem Solving and Engineering Design, McGraw-Hill, New York, NY, 1999.

(10) Nazemetz, J., "Chapter 2 - What is Design," Engineering 13x2; Engineering Design with CAD, Prentice Hall E-Source, Upper Saddle River, NJ, 2004.

(11) Cussler, E., and G. Moggridge, "Chapter 1 - An Introduction to Chemical Product Design," Chemical Product Design, Cambridge University Press, New York, NY, 2001.

(12) Jensen, J., "Chapter 7-Engineering Design Method," A Users Guide to Engineering, Prentice Hall ESource, Upper Saddle River, NJ, 2004.

(13) “Stackable vertical axis windmill” U.S. Patent 6,857,846, 